\title{
Global bathymetric patterns of standing stock and body size in the deep-sea benthos
}

\author{
Michael A. $\operatorname{Rex}^{1, *}$, Ron J. Etter ${ }^{1}$, Jeremy S. Morris ${ }^{1}$, Jenifer Crouse $^{1}$, \\ Craig R. McClain ${ }^{2}$, Nicholas A. Johnson ${ }^{3}$, Carol T. Stuart ${ }^{1}$, Jody W. Deming ${ }^{4}$, \\ Rebecca Thies ${ }^{1}$, Renee Avery ${ }^{1}$ \\ ${ }^{1}$ University of Massachusetts, Department of Biology, 100 Morrissey Blvd, Boston, Massachusetts 02125, USA \\ ${ }^{2}$ Monterey Bay Aquarium Research Institute, 7700 Sandholdt Rd, Moss Landing, California 95039, USA \\ ${ }^{3}$ Committee on Evolutionary Biology, University of Chicago, 1025 E. 57th St, Chicago, Illinois 60637, USA \\ ${ }^{4}$ University of Washington, School of Oceanography, Campus Box 357940, Seattle, Washington 98195, USA
}

\begin{abstract}
We present the first global-scale analysis of standing stock (abundance and biomass) for 4 major size classes of deep-sea biota: bacteria, metazoan meiofauna, macrofauna and megafauna. The community standing stock decreases with depth; this is a universal phenomenon that involves a complex transition in the relative importance of the different size groups. Bacterial abundance and biomass show no decline with depth. All 3 animal size groups experience significant exponential decreases in both abundance and biomass. The abundance of larger animals is significantly lower and decreases more rapidly than for smaller groups. The resulting drop in average body size with depth confirms Thiel's size-structure hypothesis on very large spatial scales. In terms of their proportion of total community biomass, smaller size classes replace larger size classes. The upper continental slope is dominated by macrofaunal biomass, and the abyss by bacterial and meiofaunal biomass. The dramatic decrease in total community standing stock and the ascendancy of smaller organisms with depth has important implications for deep-sea biodiversity. The bathyal zone (200 to $4000 \mathrm{~m}$ ) affords more ecological and evolutionary opportunity in the form of energy availability for larger organisms, and consequently supports higher macrofaunal and megafaunal species diversity than the abyss $(>4000 \mathrm{~m})$.
\end{abstract}

KEY WORDS: Deep sea · Benthos · Abundance · Biomass $\cdot$ Body size $\cdot$ Biodiversity

Resale or republication not permitted without written consent of the publisher

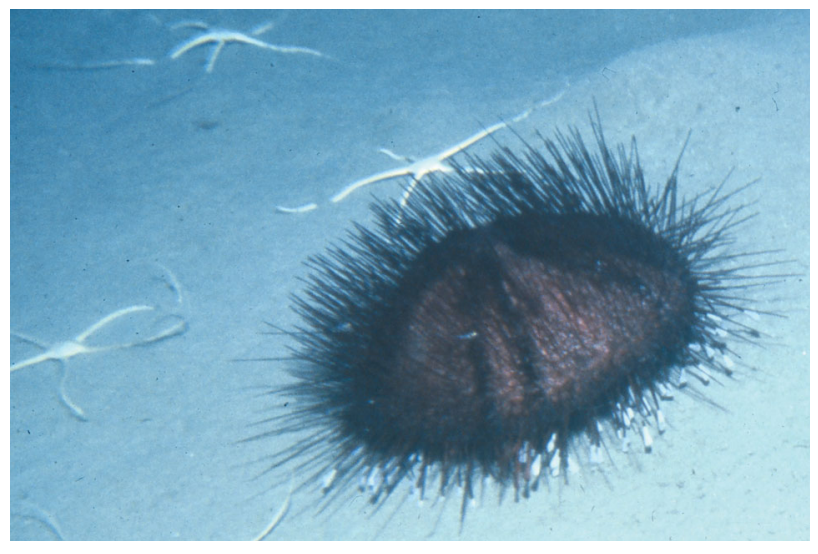

A global analysis of standing stock in the deep-sea benthos reveals that overall biomass and abundance decrease exponentially with depth. Energy constraints also result in a marked shift toward dominance of smaller organisms, and in a decrease in the abundance of megafaunal species such as the sea urchin Hygrosoma petersii and the ophiuroid Ophiomusium lymani shown here.

Photo: Ruth D. Turner

\section{INTRODUCTION}

With the exception of chemosynthetic sites, such as hydrothermal vents and cold seeps (Van Dover 2000, Tunnicliffe et al. 2003), life in the deep sea is supported by sinking organic matter that originates ultimately as surface production and sinks through the water column or is laterally advected (Gage \& Tyler 1991). The rate of nutrient input to the benthos is directly or indi- 
rectly associated with a wide range of phenomena, including community structure and organization (Rex et al. 2005), faunal composition (Carney 2005), life histories (Young 2003), trophodynamics (Rowe et al. 2003), body size (Thiel 1975), morphological diversity (McClain et al. 2004), and the potential for evolutionary diversification (Etter et al. 2005). On local scales, carbon flux to the deep seabed and its utilization by the benthos can be estimated directly by using sediment trap deployments and determining sediment community oxygen consumption (Smith et al. 2001, 2006). Currently, there are too few measurements of this type to provide a reasonably complete picture of food availability at large geographic scales. Ocean-wide maps of predicted carbon flux to the deep sea (Jahnke 1996) and organic carbon content of sediments (Seiter et al. 2004) now exist. While these are essential to understanding the global carbon cycle, their scale of resolution remains very coarse. Benthic standing stock represents a time-averaged consequence of energy input (Smith et al. 1997, Herman et al. 2001) that is positively correlated with particulate organic carbon flux (Rowe et al. 1991, Cosson et al. 1997, Danovaro et al. 1999, Smith \& Demopolous 2003) and surface-derived chloroplastic pigment equivalents in sediments (Soltwedel 2000). Seascape variation in benthic standing stock can provide important indications of ecological and evolutionary opportunity in the deep-sea ecosystem.
Since Rowe's (1983) classic review of bathymetric biomass trends in the macrofauna, a large literature has appeared documenting standing stock on local and regional scales. Here, we present the first global-scale synthesis of data on both biomass and abundance across 4 major size components of the benthic community: bacteria, and metazoan meiofauna, macrofauna and megafauna. An analysis of covariance among the groups reveals strong and consistent depth-related changes in standing stock and average body size that have an important bearing on deep-sea biodiversity.

\section{MATERIALS AND METHODS}

We compiled a database of 2310 estimates of standing stock from 128 studies (references for each group and region are provided in Appendices 1 to 3; available at www.int-res.com/articles/suppl/m317p001_ app.pdf). The distribution of sampling sites is shown in Fig. 1. Sample coverage is biased toward the Atlantic and its adjacent seas, primarily because of the proximity to long established American and European oceanographic institutions. The western South Atlantic and much of the Indo-Pacific Ocean, particularly in the Southern Hemisphere, are currently underrepresented for standing stock measurements-most of these regions remain unexplored.

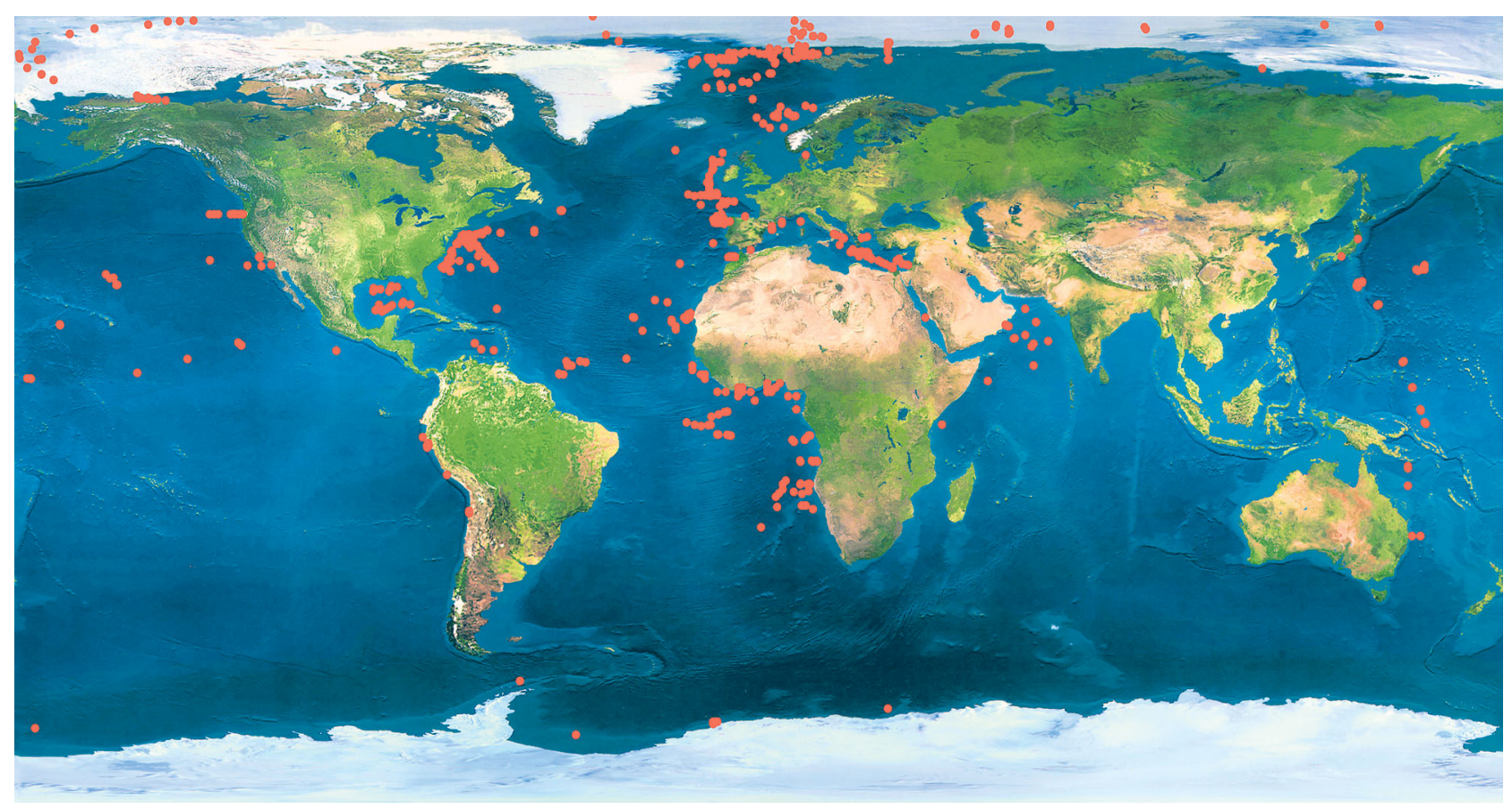

Fig. 1. Global distribution of samples used to estimate abundance and biomass of deep-sea communities. References for each size class of benthos and region are provided in Appendices 1 to 3 (available at www.int-res.com/articles/suppl/m317p001_app.pdf). Some dots represent multiple samples. Map from i Map 3.1 (www.biovolution.com) 
Bacteria, metazoan meiofauna, macrofauna and megafauna have distinctive taxonomic compositions (Gage \& Tyler 1991), and represent modes in the overall size spectrum of deep-sea organisms which suggest functional independence (Schwinghamer 1985, Lampitt et al. 1986). They also require quite different sampling methodologies. We selected studies that report standing stock for the entire assemblage of each size group, rather than only individual taxa. For bacteria, abundance is determined by DNA staining and epifluorescence microscopy, and biomass is estimated either by using a conversion factor or by biochemical quantification of phospholipid concentration. We use the term 'bacteria' in a generic sense to include members of both the bacterial and archaeal domains. The metazoan meiofauna and macrofauna in the studies represent invertebrate groups retained on sieves of 20 to $74 \mu \mathrm{m}$ and 250 to $520 \mu \mathrm{m}$ mesh size, respectively, used during sample processing. The meiofauna comprises nematodes, harpacticoid copepods and minute representatives of other taxa. The macrofauna includes a highly diverse group dominated by polychaete worms, peracarid crustaceans and mollusks. The type of quantitative sampling gear deployed and the sieve mesh size affect estimates of standing stock in the meiofauna and macrofauna (Bett et al. 1994, Gage et al. 2002). We tested for their potential influence by using partial regression. Gear and sieve mesh size do have significant independent effects in some cases, but these are very subordinate to depth. A more detailed analysis of the influence of sampling methods will be presented elsewhere. For the present analysis, the essential feature is that holding gear type and sieve mesh size statistically constant does not change the relative positions of the standing stock-depth regression lines for meiofauna and macrofauna at these very large spatial scales. The megafauna are larger centimeter- to decimeter-scale invertebrates (primarily echinoderms, cnidarians and crustaceans) and demersal fishes censused by photographic surveys and trawls. All abundance estimates were standardized to the number of individuals $\mathrm{m}^{-2}$ and biomass to $\mathrm{gC} \mathrm{m}^{-2}$ by widely used conversion formulas for weight to organic carbon content (Rowe 1983, Soltwedel 2000).

Unfortunately, it is not currently possible to create a comparable database on both density and biomass of benthic foraminiferans because of the difficulty in discriminating live from dead individuals, and determining the biomass of living protoplasm (Soltwedel 2000). Deep-sea foraminiferans are an abundant, diverse and ecologically important group (Levin et al. 1991, Bernhard 1992, Gooday et al. 1998). Some species reach macro- or even megafaunal dimensions (Gooday et al. 2002), but most are meiofaunal in size, and foraminiferans are often grouped with the meiofauna. There are very few measurements of foraminiferan biomass. The few studies that have estimated foraminiferan abundance along depth gradients suggest that it is similar to abundance of the metazoan meiofauna (e.g. Heip et al. 2001). Whether it is somewhat higher or lower than metazoan meiofaunal abundance varies among regions (cf. Gooday 1996, Soltwedel 1997a, Aller et al. 2002). Collecting more data on the geographic distribution of foraminiferan standing stock is vital to understanding community structure and function in the deep sea. If existing data on foraminiferan abundance are representative, this will reinforce our conclusions about the size structure of the benthos (see 'Results and Discussion'). Many other protozoans live in deepsea sediments (Soltwedel 1997b), but even less is known about their standing stock and biogeography.

We regressed abundance and biomass against depth from 200 to $6000 \mathrm{~m}$ for all 4 major size categories (see Figs. 2 \& 3). We used partial residuals to examine how abundance or biomass vary with depth after controlling for longitude and latitude. The partial residuals allow us to isolate the effect of depth in the multiple regression and place the results into the actual depth scale. To translate the partial residuals into an appropriate scale for the dependent variable, we added the $y$-intercept from the multiple regression. In this way, the partial residual reflects the predicted value of the dependent variable from the multiple regression if the other independent variables were held constant, and depicts how it would change in response to changes in depth.

We compared the slopes and elevations of regressions among the 4 groups by using an analysis of covariance (ANCOVA). ANCOVA can be used to compare elevations of regression lines if their slopes are not statistically different (Zar 1984). Where slopes were heterogeneous, we used Tukey multiple comparison tests (Zar 1984) to determine which combinations of slopes differ. In these cases, we applied the Johnson-Neyman test (Huitema 1980) to identify the depth range over which elevations are not significantly different.

\section{RESULTS AND DISCUSSION}

While the abundances of all 3 animal groups decrease significantly with depth, bacterial density remains constant (Fig. 2, Table 1). The slopes of all 4 groups are heterogeneous. Multiple comparisons show that slopes of 2 combinations: bacteria vs. metazoan meiofauna, and macrofauna vs. megafauna do not differ. The elevation for bacteria exceeds that for meiofauna, and the elevation for macrofauna exceeds that for megafauna. In comparisons where slopes do differ significantly, the 

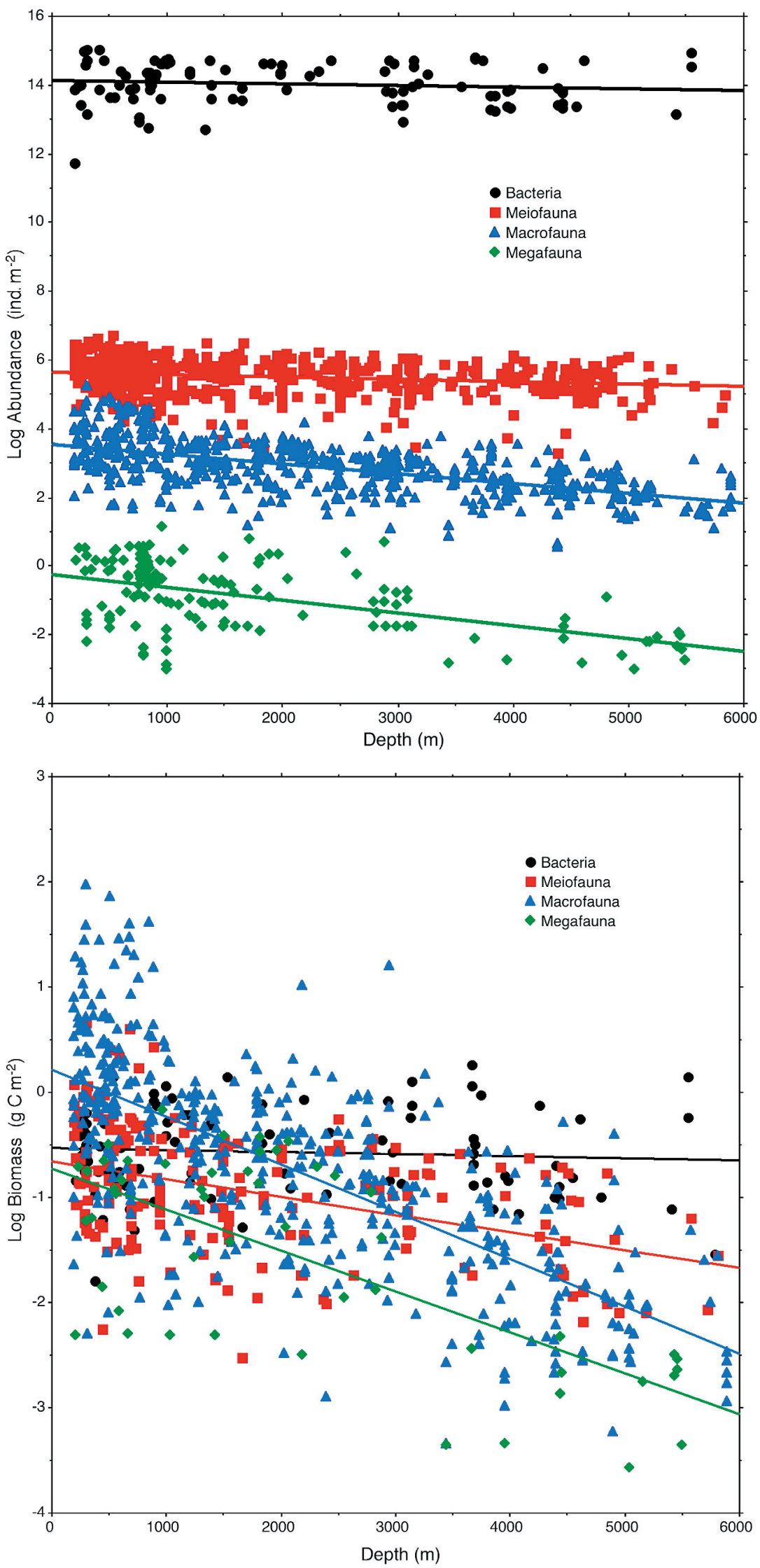

Fig. 2. Relationships of abundance to depth for bacteria, metazoan meiofauna, macrofauna and megafauna. Effects of longitude and latitude were removed by partial regression. References for the 4 size classes are provided in Appendices 1 \& 3 (available at www.int-res.com/articles/ suppl/m317p001_app.pdf). Regression equations and statistics are given in Table 1

biggest difference is that the macrofauna decreases with depth more rapidly than the meiofauna ( $Q=13.99$ vs. 8.21 to 11.26 for the other 3 significant differences). Johnson-Neyman tests show that in all 4 cases where slopes differ, the elevations are significantly different within the range of depth covered (i.e. the regression lines would cross theoretically and not be significantly different in elevation at depths shallower than $0 \mathrm{~m}$ ). Within the 200 to $6000 \mathrm{~m}$ depth range actually sampled, the sequence of significantly different abundance levels is bacteria > meiofauna > macrofauna $>$ megafauna.

Unlike abundance, there is extensive overlap in biomass among the 4 groups (Fig. 3). Again, animal biomass decreases significantly with depth, but bacterial biomass remains constant (Table 1). The slopes of all 4 groups are heterogeneous. Multiple comparisons show that slopes are the same for macrofauna and megafauna, and that elevation is highest for the macrofauna. The biomass of bacteria is significantly higher than that of the metazoan meiofauna over most of the depth range covered (>547 m). The macrofauna shows a shift in biomass relative to other groups. It has higher biomass than bacteria above $1233 \mathrm{~m}$, but lower below 2177 m. Similarly, macrofaunal biomass is higher than meiofaunal biomass above $2527 \mathrm{~m}$, but lower below $4069 \mathrm{~m}$. Biomass of the megafauna is significantly less than the macrofauna throughout the depth range, less than bacteria below $382 \mathrm{~m}$, and less than meiofauna

Fig. 3. Relationships of biomass to depth for bacteria, metazoan meiofauna, macrofauna and megafauna. Effects of longitude and latitude were removed by partial regression. References for the 4 size classes are provided in Appendices 2 \& 3 (available at www.int-res.com/ articles/suppl/m317p001_app.pdf). Regression equations and statistics are given in Table 1 
below $1004 \mathrm{~m}$. Overall, there is a change in the biomass hierarchy among groups, with macrofauna dominating at upper bathyal depths, and a progressive emphasis toward smaller size classes with increasing depth across the bathyal zone to the abyssal plain where smaller organisms reign and the sequence of biomass becomes bacteria $>$ meiofauna $>$ macrofauna $>$ megafauna.

Our results show that the dramatic decrease in standing stock with depth in the 3 animal size categories, long recognized on regional scales for separate groups (Gage \& Tyler 1991), is a very general phenomenon in the deep sea. There is now wide acceptance that this decline is caused by the exponential decrease in the rate of nutrient input from sinking phytodetritus with increasing depth and distance from productive coastal waters. Standing stock in all 4 groups can be predicted by rates of particulate organic carbon flux or chloroplastic pigment equivalents in sediments (Sibuet et al. 1989, Deming \& Yager 1992, Soltwedel 2000, Smith \& Demopoulos 2003).

Our analysis provides the first detailed look at how the decrease in organic carbon input with depth reshapes benthic community structure along depth gradients. Bacterial abundance remains high and constant throughout the depth range (Fig. 2). The regression for abundance of the smaller metazoan meiofauna is significantly higher and less steep than for the macrofauna, indicating that average animal size in the community as a whole must decrease with depth. The megafaunal abundance-depth regression reinforces this. It is significantly lower than that for the bacteria and meiofauna, and is also steeper than the meiofaunal regression. In other words, with increasing depth the community becomes more dominated by smaller organisms. If foraminiferan abundance is similar to metazoan meiofaunal abundance as suggested earlier, then this trend is augmented. The biomass data corroborate the trend toward smaller size (Fig. 3). At upper bathyal depths macrofaunal biomass is higher than both bacterial and meiofaunal biomass. However, macrofaunal and megafaunal biomass decline more rapidly with depth, and at abyssal depths the biomass levels of meiofauna and bacteria become proportionately higher. The dominance of macrofaunal biomass on the upper slope (Aller et al. 2002), dominant bacterial biomass in the abyss (Rowe et al. 1991, 2003), an increase in the meiofaunal:macrofaunal density ratio with depth (Flach et al. 2002), steeper rates of decline in density of larger organisms (Heip et al. 2001), and an increase in the representation of smaller groups from eutrophic to oligotrophic sites (Galéron et al. 2000) have been observed earlier, but the global-scale analysis presented here shows the transformation of community structure among all size categories across the full depth range.
Table 1. Regression analyses and ANCOVAs for abundance (ind. $\mathrm{m}^{-2}$ ) and biomass $\left(\mathrm{gC} \mathrm{m}^{-2}\right)$ against depth for bacteria, metazoan meiofauna, macrofauna and megafauna. See Figs. 2 and 3 for plots of regressions. The dependent variables are log of abundance and biomass with the effects of longitude and latitude removed by partial regression. Inequality signs indicate a significant $(\mathrm{p}<0.05)$ difference and the direction of the difference. For comparisons where slopes differ, the Johnson-Neyman (JN) test provides the depth range (m) over which the regression lines compared do not differ significantly in elevation. B: bacteria; Me: metazoan meiofauna; Ma: macrofauna; Mg: megafauna. ${ }^{*} p<0.05,{ }^{* *} p<0.01,{ }^{* * *} p<$ $0.001,{ }^{* * * *} \mathrm{p}<0.0001$, n.s.: not significant; N: no. of individuals

\begin{tabular}{|c|c|c|c|c|}
\hline Regressions & \multicolumn{2}{|c|}{ Equations } & $\mathrm{N}$ & $F$ \\
\hline \multicolumn{5}{|l|}{ Abundance } \\
\hline $\mathrm{B}$ & \multicolumn{2}{|c|}{$Y=14.137-0.000040 X$} & 111 & 1.303 n.s. \\
\hline $\mathrm{Me}$ & \multicolumn{2}{|c|}{$Y=5.644-0.000068 X$} & 594 & $27.188^{* * * *}$ \\
\hline Ма & \multicolumn{2}{|c|}{$\mathrm{Y}=3.547-0.00028 \mathrm{X}$} & 656 & $355.412^{* * * *}$ \\
\hline $\mathrm{Mg}$ & \multicolumn{2}{|c|}{$\mathrm{Y}=-0.245-0.00037 \mathrm{X}$} & 148 & $52.417^{* * * *}$ \\
\hline \multicolumn{5}{|l|}{ Biomass } \\
\hline B & \multicolumn{2}{|c|}{$Y=-0.523-0.000020 X$} & 99 & 0.609 n.s. \\
\hline $\mathrm{Me}$ & \multicolumn{2}{|c|}{$Y=-0.656-0.00017 X$} & 191 & $41.375^{* * * *}$ \\
\hline Мa & \multicolumn{2}{|c|}{$Y=0.219-0.00045 X$} & 460 & $447.682^{* * * *}$ \\
\hline $\mathrm{Mg}$ & \multicolumn{2}{|c|}{$\mathrm{Y}=-0.734-0.00039 \mathrm{X}$} & 51 & $43.992^{* * * *}$ \\
\hline ANCOVA & & df & & $F$ \\
\hline \multicolumn{5}{|l|}{ Abundance } \\
\hline \multicolumn{2}{|l|}{ Slope } & 3,1501 & & $46.911^{* * *}$ \\
\hline Elevation & & 3,1504 & & $14.554 .95^{* * *}$ \\
\hline \multicolumn{5}{|l|}{ Biomass } \\
\hline \multirow{2}{*}{\multicolumn{2}{|c|}{$\begin{array}{l}\text { Slope } \\
\text { Elevation }\end{array}$}} & 3,793 & & $43.129^{* * *}$ \\
\hline & & 3,796 & & $32.367^{* * *}$ \\
\hline \multicolumn{2}{|c|}{ Multiple comparisons } & Slope & Elevation & JN test \\
\hline \multicolumn{5}{|l|}{ Abundance } \\
\hline \multicolumn{2}{|l|}{$\mathrm{B}-\mathrm{Me}$} & n.s & \multirow[t]{2}{*}{$\mathrm{B}>\mathrm{Me}$} & \\
\hline \multicolumn{2}{|l|}{ B-Ma } & $\mathrm{B}<\mathrm{Ma}$ & & 0 \\
\hline \multicolumn{2}{|l|}{$\mathrm{B}-\mathrm{Mg}$} & $\mathrm{B}<\mathrm{Mg}$ & & 0 \\
\hline \multicolumn{2}{|l|}{ Me-Ma } & $\mathrm{Me}<\mathrm{Ma}$ & & 0 \\
\hline \multicolumn{2}{|l|}{$\mathrm{Me}-\mathrm{Mg}$} & $\mathrm{Me}<\mathrm{Mg}$ & & 0 \\
\hline \multicolumn{2}{|l|}{$\mathrm{Ma}-\mathrm{Mg}$} & n.s. & $\mathrm{Ma}>\mathrm{Mg}$ & \\
\hline \multicolumn{5}{|l|}{ Biomass } \\
\hline \multicolumn{2}{|l|}{$\mathrm{B}-\mathrm{Me}$} & $\mathrm{B}<\mathrm{Me}$ & & $200-547$ \\
\hline \multicolumn{2}{|l|}{ B-Ma } & $\mathrm{B}<\mathrm{Ma}$ & & $1233-2177$ \\
\hline \multicolumn{2}{|l|}{$\mathrm{B}-\mathrm{Mg}$} & $\mathrm{B}<\mathrm{Mg}$ & & $200-382$ \\
\hline Me-Ma & & $\mathrm{Me}<\mathrm{Ma}$ & & $2527-4069$ \\
\hline $\mathrm{Me}-\mathrm{Mg}$ & & $\mathrm{Me}<\mathrm{Mg}$ & & 200-1004 \\
\hline $\mathrm{Ma}-\mathrm{Mg}$ & & n.s. & $\mathrm{Ma}>\mathrm{Mg}$ & \\
\hline
\end{tabular}

It is notable that the biomass and abundance of bacteria remain so high at abyssal depths in view of the sharp decline in animal standing stock. An earlier review of microbial-mediated diagenesis in the marine environment found only weak evidence for a decrease in standing stock with depth in the deep sea (Deming \& Baross 1993); some recent regional studies have again found weak to no evidence for such a decrease (Dixon \& Turley 2000, Deming \& Carpenter 2003). The 
abundance of bacteria in surficial sediments scales to porewater volume in a relatively constant way, regardless of depth or organic content of sediments (Schmidt et al. 1998). Bacterial standing stock does not necessarily correlate with metabolic activity. There is ample evidence for distinctive barophilic microbiota that rapidly degrade sinking phytoplankton (Deming 1985, Lochte \& Turley 1988), but an unknown fraction of bacteria in deep-sea sediments originates in surface waters and is transported to the seafloor attached to sinking phytodetritus (Lochte \& Turley 1988). Many of these appear to be dormant, either because they lack labile organic material or because of inhibitory physical conditions at great depths (Deming \& Baross 2000). Determining the relative proportions of active and inactive bacteria in deep-sea sediments, and why such high standing stocks accumulate, remain major challenges in deep-sea ecology. A recent methodological development appears promising in this regard (Quéric et al. 2004).

The decrease in average organism size with depth supports Thiel's $(1975,1979)$ size-structure hypothesis. Using data on meiofauna and macrofauna, he demonstrated the same divergence of abundance-depth regressions shown here, implying an increased proportion of smaller organisms with increased depth. Subsequent tests of Thiel's hypothesis produced mixed results (cf. Shirayama 1983, Sibuet et al. 1989, Schewe \& Soltwedel 1998). The community-wide analyses of both abundance and biomass presented here provide strong confirmation that smaller size classes become dominant at greater depths. The reduction in average organism size with depth is the most conspicuous and consistent biogeographic trend in the deep-sea benthos.

While the average size of organisms decreases with depth, large megafaunal species are well represented at abyssal depths (Figs. $2 \& 3$ ), and have an important ecological role (Billett et al. 2001, Ruhl \& Smith 2004). Scavenging amphipods (Hessler et al. 1972) living at abyssal depths actually exhibit gigantism; they are much larger than typical peracarid crustaceans. These organisms are highly mobile, and are adapted to quickly locate and consume large deadfalls. Their unusual size may be a response to a different set of selective pressures than those affecting smaller sedentary members of the community. The apparent dichotomy between gigantism in a minority of species and the more pervasive size reduction in deep-sea benthos presents an interesting and unresolved theoretical problem.

Fig. 3 supports Haedrich \& Rowe's (1977) contention, based on the similarity of macrofaunal and megafaunal biomass in the western North Atlantic, that the smallto-large size class series does not correspond to lowto-high trophic levels in a food chain. Over most of the depth range, biomass values for the 4 groups are not separated by order of magnitude differences as expected in a typical food pyramid; and regression lines actually cross, reversing the relative positions in the biomass hierarchy. While there obviously must be some energy transfer from bacteria and meiofauna to larger organisms, the patterns of biomass are more consistent with a complex, coevolved food web containing a variety of feeding types within each of the animal size classes, multiple points of entry for particulate and dissolved organic carbon, and an integrated benthic microbial loop (Deming \& Baross 1993, Rowe et al. 2003).

The steeper regressions for both abundance and biomass of the macrofauna and megafauna, compared to smaller size groups, suggest that large organisms are more affected by the reduction in available energy with depth. Larger organisms have more efficient metabolism per unit weight, but still require more energy than small organisms. At great depths, the population densities of larger organisms may become too low, due to energy restrictions, to remain reproductively viable (Rex 1973, Thiel 1975, Rex et al. 2005). If so, this has important implications, not only for the size structure of deep-sea communities, but also for hypotheses on the causes of biodiversity patterns. Abyssal macrofaunal and megafaunal species diversities are depressed (Rex 1981). For one important macrofaunal taxon, mollusks, the abyssal fauna is composed largely of sparsely occupied range extensions for a subset of bathyal species with larval dispersal (Rex et al. 2005). There is little evidence of abyssal endemism (McClain et al. in press). The bathyal and abyssal zones may function as a source-sink system in which abyssal populations of many macrofaunal species are not reproductively self-sustaining, but represent a balance between chronic local extinction from inverse density dependence and immigration from bathyal sources (Rex et al. 2005). Extremely low abundance and biomass may also constrain the potential for evolutionary diversification in larger size groups (Etter et al. 2005). Even if speciation is successful in terms of producing reproductively isolated populations, food levels in the abyss may be insufficient to support subsequent coexistence. Patterns of standing stock suggest that there is considerably more ecological and evolutionary opportunity for adaptive radiation in the bathyal zone (200 to $4000 \mathrm{~m}$ ) than in the abyss (>4000 m).

Acknowledgements. This research was supported by a National Science Foundation grant (OCE-0135949) to M.A.R. Maria Mahoney helped to prepare the manuscript. Thomas Soltwedel and Ingrid Krönke generously provided unpublished data, and Andrea Rex read the manuscript. The editor, Lisa Levin, and anonymous reviewers provided very helpful comments and suggestions. 


\section{LITERATURE CITED}

Aller JY, Aller RC, Green MA (2002) Benthic faunal assemblages and carbon supply along the continental shelf/shelf break-slope off Cape Hatteras, North Carolina. Deep-Sea Res II 49:4599-4625

Bernhard JM (1992) Benthic foraminiferal distribution and biomass related to pore-water oxygen content: Central California continental slope and rise. Deep-Sea Res 39:585-605

Bett BJ, Vanreusel A, Vincx M, Soltwedel T and 5 others (1994) Sampler bias in the quantitative study of deep-sea meiobenthos. Mar Ecol Prog Ser 104:197-203

Billett DSM, Bett BJ, Rice AL, Thurston MH, Galéron J, Sibuet M, Wolff GA (2001) Long-term change in the megabenthos of the Porcupine Abyssal Plain (NE Atlantic). Prog Oceanogr 50:325-348

Carney RS (2005) Zonation of deep biota on continental margins. Oceanogr Mar Biol Annu Rev 43:211-278

Cosson N, Sibuet M, Galéron J (1997) Community structure and spatial heterogeneity of the deep-sea macrofauna at 3 contrasting stations in the tropical northeast Atlantic. Deep-Sea Res I 44:247-269

Danovaro R, Dinet A, Duineveld G, Tselepides A (1999) Benthic response to particulate fluxes in different trophic environments: a comparison between Gulf of LionsCatalan Sea (western-Mediterranean) and the Cretan Sea (eastern-Mediterranean). Prog Oceanogr 44:287-312

Deming JW (1985) Bacterial growth in deep sediment trap and boxcore samples. Mar Ecol Prog Ser 25:305-312

Deming JW, Baross JA (1993) The early diagenesis of organic matter: bacterial activity. In: Engel $\mathrm{MH}$, Macko SA (eds) Organic geochemistry. Plenum Press, New York, p 119-144

Deming JW, Baross JA (2000) Survival, dormancy, and nonculturable cells in extreme deep-sea environments. In: Colwell RR, Grimes DJ (eds) Nonculturable microorganisms in the environment. AMS Press, Washington, DC, p $147-197$

Deming JW, Carpenter SD (2003) Factors influencing benthic bacterial abundance and activity on the northern continental slope of the Gulf of Mexico. Oceanography 16:35

Deming JW, Yager PL (1992) Natural bacterial assemblages in deep-sea sediments: toward a global view. In: Rowe GT, Pariente V (eds) Deep-sea food chains and the global carbon cycle. Kluwer, Dordrecht, p 11-27

Dixon JL, Turley CM (2000) The effect of water depth on bacterial numbers, thymidine incorporation rates and $\mathrm{C}: \mathrm{N}$ ratios in northeast Atlantic surficial sediments. Hydrobiologia 440:217-225

Etter RJ, Rex MA, Chase MR, Quattro JM (2005) Population differentiation decreases with depth in deep-sea bivalves. Evolution 59:1479-1491

Flach E, Muthumbi A, Heip C (2002) Meiofauna and macrofauna community structure in relation to sediment composition at the Iberian margin compared to the Goban Spur (NE Atlantic). Prog Oceanogr 52:433-457

Gage JD, Tyler PA (1991) Deep-sea biology: a natural history of organisms at the deep-sea floor. Cambridge University Press, Cambridge

Gage JD, Hughes DJ, Gonzalez Vecino JL (2002) Sieve size influence in estimating biomass, abundance and diversity in samples of deep-sea macrobenthos. Mar Ecol Prog Ser 225:97-107

Galéron J, Sibuet M, Mahaut ML, Dinet A (2000) Variation in structure and biomass of the benthic communities at three contrasting sites in the tropical Northeast Atlantic. Mar Ecol Prog Ser 197:121-137
Gooday AJ (1996) Epifaunal and shallow infaunal foraminiferal communities at three abyssal NE Atlantic sites subject to differing phytodetritus input regimes. Deep-Sea Res I 43:1395-1421

Gooday AJ, Bett BJ, Shires R, Lambshead PJD (1998) Deepsea benthic foraminiferal species diversity in the NE Atlantic and NW Arabian Sea: a synthesis. Deep-Sea Res I 45:165-201

Gooday AJ, Pond DW, Bowser SS (2002) Ecology and nutrition of the large agglutinated foraminiferan Bathysiphon capillare in the bathyal NE Atlantic: distribution within the sediment profile and lipid biomarker composition. Mar Ecol Prog Ser 245:69-82

Haedrich RL, Rowe GT (1977) Megafaunal biomass in the deep sea. Nature 269:141-142

Heip CHR, Duineveld G, Flach E, Graf G and 11 others (2001) The role of the benthic biota in sedimentary metabolism and sediment-water exchange processes in the Goban Spur area (NE Atlantic). Deep-Sea Res II 48:3223-3243

Herman PMJ, Soetaert K, Middelburg JJ, Heip C and 5 others (2001) The seafloor as the ultimate sediment trap - using sediment properties to constrain benthic-pelagic exchange processes at the Goban Spur. Deep-Sea Res II 48: 3245-3264

Hessler RR, Isaacs JD, Mills EL (1972) Giant amphipod from the abyssal Pacific Ocean. Science 175:636-637

Huitema BE (1980) The analysis of covariance and alternatives. Wiley, New York

Jahnke RA (1996) The global ocean flux of particulate organic carbon: areal distribution and magnitude. Global Biogeochem Cycles 10:71-88

Lampitt RS, Billett DSM, Rice AL (1986) Biomass of the invertebrate megabenthos from 500 to $4100 \mathrm{~m}$ in the northeast Atlantic Ocean. Mar Biol 93:69-81

Levin L, Childers SE, Smith CR (1991) Epibenthic, agglutinating foraminiferans in the Santa Catalina Basin and their response to disturbance. Deep-Sea Res 38:465-483

Lochte K, Turley CM (1988) Bacteria and cyanobacteria associated with phytodetritus in the deep sea. Nature 333: 67-69

McClain CR, Johnson NA, Rex MA (2004) Morphological disparity as a biodiversity metric in lower bathyal and abyssal gastropod assemblages. Evolution 58:338-348

McClain CR, Rex MA, Etter RJ (in press) Patterns in deep-sea macroecology. In: Witman J, Roy K (eds) Marine macroecology. University of Chicago Press, Chicago

Quéric NV, Soltwedel T, Arntz WE (2004) Application of a rapid direct viable count method to deep-sea sediment bacteria. J Microbiol Methods 57:351-367

Rex MA (1973) Deep-sea species diversity: decreased gastropod diversity at abyssal depths. Science 181:1051-1053

Rex MA (1981) Community structure in the deep-sea benthos. Annu Rev Ecol Syst 12:331-353

Rex MA, McClain CR, Johnson NA, Etter RJ, Allen JA, Bouchet P, Warén A (2005) A source-sink hypothesis for abyssal biodiversity. Am Nat 165:163-178

Rowe GT (1983) Biomass and production of the deep-sea macrobenthos. In: Rowe GT (ed) The sea, Vol 8, Deep-sea biology. Wiley, New York, p 97-122

Rowe GT, Sibuet M, Deming J, Khripounoff A, Tietjen J, Macko S, Theroux R (1991) 'Total' sediment biomass and preliminary estimates of organic carbon residence time in deep-sea benthos. Mar Ecol Prog Ser 79:99-114

Rowe GT, Lohse A, Hubbard F, Boland GS, Escobar Briones E, Deming J (2003) Preliminary trophodynamic carbon budget for the Sigsbee Deep benthos, Northern Gulf of Mexico. Am Fish Soc Symp 36:225-238 
Ruhl HA, Smith KL Jr (2004) Shifts in deep-sea community structure linked to climate and food supply. Science 305: 513-515

Schewe I, Soltwedel T (1998) Deep-sea meiobenthos of the central Arctic Ocean: distribution patterns and size-structure under extreme oligotrophic conditions. Vie Milieu 49:79-92

Schmidt JL, Deming JW, Jumars PA, Keil RG (1998) Constancy of bacterial abundance in surficial marine sediments. Limnol Oceanogr 43:976-982

Schwinghamer P (1985) Observations on size-structure and pelagic coupling of some shelf and abyssal benthic communities. In: Gibbs PE (ed) Proc 19th Eur Mar Biol Symp. Cambridge University Press, Cambridge, p 347-359

Seiter K, Hensen C, Schröter J, Zabel M (2004) Organic carbon content in surface sediments - defining regional provinces. Deep-Sea Res I 51:2001-2026

Shirayama Y (1983) Size structure of deep-sea meio- and macrobenthos in the Western Pacific. Int Rev Gesamt Hydrobiol 68:799-810

Sibuet M, Lambert CE, Chesselet R, Laubier L (1989) Density of the major size groups of benthic fauna and trophic input in deep basins of the Atlantic Ocean. J Mar Res 47: 851-867

Smith CR, Demopoulos AWJ (2003) The deep Pacific Ocean floor. In: Tyler PA (ed) Ecosystems of the deep oceans. Elsevier, Amsterdam, p 179-218

Smith CR, Berelson W, DeMaster DJ, Dobbs FC, Hammond D, Hoover DJ, Pope RH, Stephens M (1997) Latitudinal variations in benthic processes in the abyssal equatorial Pacific: control by biogenic particle flux. Deep-Sea Res II 44:2295-2317

Editorial responsibility: Lisa Levin (Contributing Editor), La Jolla, California, USA
Smith KL Jr, Kaufmann RS, Baldwin RJ, Carlucci AF (2001) Pelagic-benthic coupling in the abyssal eastern North Pacific: an 8-year time-series study of food supply and demand. Limnol Oceanogr 46:543-556

Smith KL Jr, Baldwin RJ, Ruhl HA, Kahru M, Mitchell BG, Kaufman RS (2006) Climate effect on food supply to depths greater than 4,000 meters in the northeast Pacific. Limnol Oceanogr 51:166-176

Soltwedel T (1997a) Meiobenthos distribution pattern in the tropical East Atlantic: indication for fractionated sedimentation of organic matter to the sea floor? Mar Biol 129: $747-756$

Soltwedel T (1997b) Temporal variabilities in benthic activity and biomass on the western European continental margin. Oceanol Acta 20:871-879

Soltwedel T (2000) Metazoan meiobenthos along continental margins: a review. Prog Oceanogr 46:59-84

Thiel H (1975) The size structure of the deep-sea benthos. Int Rev Gesamt Hydrobiol 60:576-606

Thiel H (1979) Structural aspects of the deep-sea benthos. Ambio Spec Rep 6:25-31

Tunnicliffe V, Juniper SK, Sibuet M (2003) Reducing environments of the deep-sea floor. In: Tyler PA (ed) Ecosystems of the deep oceans. Elsevier, Amsterdam, p 81-110

Van Dover CL (2000) The ecology of deep-sea hydrothermal vents. Princeton University Press, Princeton

Young CM (2003) Reproduction, development and life history traits. In: Tyler PA (ed) Ecosystems of the deep oceans. Elsevier, Amsterdam, p 381-426

Zar JH (1984) Biostatistical analysis. Prentice-Hall, Englewood Cliffs, NJ

Submitted: February 27, 2006; Accepted: May 22, 2006

Proofs received from author(s): June 28, 2006 